\title{
MATHEMATICAL RELIABILITY MODEL OF BUILDING COMPONENTS BY RAYLEIGH
}

\author{
Beata NOWOGOŃSKA ${ }^{1}$ \\ University of Zielona Gora, Institute of Building Engineering, Poland
}

\begin{abstract}
The patterns of process situations play an important role in the monitoring of diagnostic processes. The adaptation of mathematical models describing the degradation processes in mechanical and electronic devices creates opportunities to develop diagnostic standards for buildings erected in traditional technology. This article presents a proposal for the prediction of building operational reliability, which is a prognostic process model within the full period of its use.
\end{abstract}

Keywords: reliability prediction, degree of technical wear, Rayleigh distribution

\section{INTRODUCTION}

All technical objects suffer breakdowns and damages with the passage of time. The main problem arising while buildings are in use is their reliability and the endeavor to eliminate the formation of any damages.

The presented analysis includes apartment buildings erected in a traditional technology and regards them as technical objects. In the case of such buildings it is proposed to apply rules applied for mechanical and electrical objects. For the needs of the reliability analysis of apartment buildings erected in a traditional technology, a building was divided into components which were analysed first separately and then together in the whole building. The probability of the exploitation of a building without any breakdowns in a given period of time is defined as exploitation reliability.

\footnotetext{
${ }^{1}$ Corresponding author: University of Zielona Gora, Institute of Building Engineering, Szafrana str 1, 65-516 Zielona Gora, Poland, e-mail: b.nowogonska@ib.uz.zgora.pl, tel. +48683282290
} 
A complex analysis of building reliability should include phenomena accompanying long-time exploitation of a building. The following criteria are used for reliability estimation: wear, the frequency of maintenance work, the way of exploitation, the influence of external factors, the propriety of the project process, the quality of materials, the precision of the building erection work. In the case of buildings older than 100 years there are no possibilities of examining the three last factors. For a long period of exploitation, it can be assumed that designing processes and erection works were performed correctly and the used materials were of high quality. It was also assumed that the way of exploitation and the influence of external factors for all buildings were on the same level, and did not condition the differences in building reliability and thus, they were disregarded in the analysis.

\section{RELIABILITY OF TECHNICAL OBJECTS}

The analysis of numerous physical phenomena may often lead to a conclusion that some properties change randomly and, at the same time, depend on changes of other parameters. A mathematical model of such phenomena goes far beyond the classical theory of probability, where only random events and random variables are considered. The extension of the probability theory which allows the examination of random events in connection with a certain parameter (e.g. time) is the theory of stochastic processes.

The theory of renewal and reliability includes problems where the random variable $\mathrm{T}$, which refers to the lifespan of an object or its components, plays the basic role. The cumulative distribution function of the random variable $\mathrm{T}$

$$
\mathrm{F}(\mathrm{t})=\mathrm{P}\{\mathrm{T} \leq \mathrm{t}\}
$$

Is called a failure function whereas the function

$$
\mathrm{R}(\mathrm{t})=1-\mathrm{F}(\mathrm{t})
$$

is determined as a reliability function $[3,6,7,9]$. The reliability of an object is defined as the ability to fulfil the task resulting from the purpose it was intended for $[5,6,9]$.

The reliability of an object is defined as the ability to fulfil the task resulting from the purpose it was intended for. It means that the object is demanded to fulfil a determined function in determined time $t$ in determined conditions of operation. The measure of the reliability of an object, in terms of the task, is the probability of completion of the task. Such determined reliability measure is a function of time of the building's reliable performance and is called a reliability 
function $[2,8,12,14]$. To model a situation for the needs of the survival analysis, when the probability changes in time, the Weibull distribution is most frequently used as a distribution of the random variable of the time of the building's usefulness $[17,8,9,5,6,12,14,19]$. The probability density function for the Weilbull distribution is determined with the relation:

$$
f(t)=\alpha \beta^{\alpha} t^{\alpha-1} \exp \left[-(\beta t)^{\alpha}\right] \quad \text { for } t \geq 0
$$

where: $\mathrm{t}$ - the exploitation period,

$\alpha$ - scale parameter (a real number), $\alpha>0$,

$\beta$ - the shape parameter (real number), $\beta>0$.

The parameter $\alpha$ of the distribution determines the probability of a breakdown in time:

- for $\alpha<1$ the probability of breakdown decreases in time, which suggests that, when the object breakdown is modeled, some specimen may have production defects and slowly fall out of the population,

- for $\alpha=1$ (exponential distribution) the probability is constant, it indicates the fact that breakdowns are caused by external random events,

- for $\alpha>1$ the probability grows in time, which suggests that the time-related technical wear of elements is the main cause of breakdowns,

- for $\alpha=2$ (the Rayleigh distribution) the probability grows linearly in time.

The distribution parameter $\beta$ is a coefficient characterising the rate of the reliability obsolescence:

$$
\beta=1 / \mathrm{T}_{\mathrm{R}}
$$

where $\mathrm{T}_{\mathrm{R}}$ denotes the period of the object durability.

It may be interpreted as a period after which $1-1 / \mathrm{e} \approx 63.2 \%$ of the population will vanish, and is called the characteristic value of survival.

The distribution function for the Weilbull distribution obtained after integration:

$$
\mathrm{F}(\mathrm{t})=1-\exp \left[-(\beta \mathrm{t})^{\alpha}\right]
$$

In literature, the distribution function is called the probability of damage, a destruction function, breakdown or a failure function and is determined with the relation:

$$
\mathrm{F}(\mathrm{t})=\mathrm{P}\left(\mathrm{t}<\mathrm{T}_{\mathrm{R}}\right)=1-\mathrm{R}(\mathrm{t})
$$


where: $T_{R}$ - period of object durability,

$\mathrm{R}(\mathrm{t})$ - reliability function, also called the probability of proper operation, or durability function.

Inefficient or failure-free operations are opposite events which exclude one another, therefore the relation (2.6) may be applied.

The reliability function is the change of the probability of faultlessness over time, with the Weibull density distribution:

$$
R(t)=\exp \left[-(\beta t)^{\alpha}\right]
$$

The intensity of damages $\lambda(\mathrm{t})$ is a reliability indicator, which is also defined as the intensity of the probability of damage, or the rate of growth of unreliability in relation to reliability $[8,12,14]$ :

$$
\lambda(\mathrm{t})=\frac{\mathrm{d} \mathrm{F}(\mathrm{t})}{\mathrm{dt}} \frac{1}{\mathrm{R}(\mathrm{t})}
$$

Exponential distribution is a particular case of the Weibull's distribution, where th shape parameter $\alpha=1$. Exponential distribution is frequently used in the examination of a proper performance time $[2,8,10,12,14,17]$. The characteristic for the exponential distribution is a constant intensity of damages throughout the whole period of the object exploitation $\lambda(t)=$ const

$$
\lambda(t)=1 / T_{R}
$$

The relation defining the reliability function (2.7) for the i-th component of a building for known parameters $\alpha$ and $\beta$ may take the form:

$$
\mathrm{R}_{\mathrm{i}}(\mathrm{t})=\exp \left[-\left(\mathrm{t} / \mathrm{T}_{\mathrm{Ri}}\right)\right]
$$

where:

$$
\begin{array}{cl}
\mathrm{R}_{\mathrm{i}}(\mathrm{t}) & \text { - exploitation reliability for the } \mathrm{i} \text {-th component of a building, } \\
\mathrm{t} & \text { - exploitation time, } \\
\mathrm{T}_{\mathrm{Ri}} & \text { - durability period of the } \mathrm{i} \text {-th element of a building. }
\end{array}
$$

Another particular case of Weilbull distribution, where $\alpha=2$ is the Rayleigh distribution. The distribution is a one-parameter distribution, and occurs when the technical wear of the object in time is the main cause of failure [17].

The application of the Rayleigh distribution for buildings seems to be the best choice. All buildings and their components are subject to technical wear and the Rayleigh distribution is applied when the wear of an object increases in time.

For this case, the reliability function (formula 2.7) takes the form: 


$$
\mathrm{R}_{\mathrm{i}}(\mathrm{t})=\exp \left[-\left(\mathrm{t} / \mathrm{T}_{\mathrm{Ri}}\right)^{2}\right]
$$

The intensity of failure according to the Rayleigh distribution

$$
\lambda(t)=2 t / T^{2} t^{2}
$$

The bibliography on reliability of electronic devices attributes the intensity of failure to technical wear as described in:

$$
\mathrm{S}_{\mathrm{z}}=\int_{0}^{\mathrm{t}} \lambda(\mathrm{t}) \mathrm{dt}
$$

where: $S_{z}$ - technical wear.

After appropriate transformations, technical wear equals:

$$
\mathrm{S}_{\mathrm{z}}=\frac{1}{\alpha} \alpha \beta^{\alpha} \mathrm{t}^{\alpha}
$$

The degree of technical wear is thus determined with the relation:

$$
\mathrm{S}_{\mathrm{Z}}=\beta^{\alpha} \mathrm{t}^{\alpha}
$$

The technical wear according to the exponential distribution, where the intensity of failure is constant (2.9) is expressed with the linear function:

$$
\mathrm{S}_{\mathrm{Z}}=\mathrm{t} / \mathrm{T}_{\mathrm{R}}
$$

where:

$\mathrm{S}_{\mathrm{Z}}$ - the degree of technical wear of an object expressed in percentage,

$\mathrm{t}$ - the age of the object,

$\mathrm{T}_{\mathrm{R}}$ - the expected durability period of an object expressed in years.

The formula (2.16) is applied to determine the rate of technical wear and tear of carelessly maintained buildings. Due to the negligence in the renovation-repair policy, the most unfavourable variant of the determination of the rate of wear of buildings was applied.

The result of the differentiation is the constant intensity of damages, which is a characteristic feature for the exponential distribution, thus, the Weibull distribution takes the form of an exponential distribution. The relation obtained 
is one of the time methods applied for the determination of technical wear of carelessly maintained buildings in an arbitrary period of time.

For the Rayleigh distribution, where $\alpha=2, \beta=1 / T_{R}$, the degree of technical wear equals:

$$
\mathrm{S}_{\mathrm{Z}}=\mathrm{t}^{2} / \mathrm{T}_{\mathrm{R}}^{2}
$$

The formula (2.17) is applied to determine the rate of technical wear and tear of well- maintained buildings.

\section{RELIABILITY PREDICTION OF BUILDING COMPONENTS}

The research included the specification of building components which were first analyzed separately and then together in the whole building. Each component is made of various building materials. Over time, all materials are subject to ageing and natural wear, and lose their original exploitation properties. The process is different for each building component and they are all characterized by their own durability periods $[1,4,11,13,16,18]$.

The time of exploitation during which the components lose their exploitation properties depends on many factors: the material quality, the structure solutions, the performance quality of the building erection work, the influence of the environment, the way and conditions of building exploitation. The factors may occur with various frequency and intensity. Due to the complexity of the phenomena, the durability periods are time periods of various lengths. For respective building components and solutions, average durability periods $T_{R i}$ may be assumed. They are values for average performance quality of the building erection work and building exploitation as well as average environmental conditions.

To determine the exploitation reliability of a building with the use of the relations (2.10) and (2.11), the building, erected in the traditional technology, was divided into 25 components (brick foundations, masonry brick walls, masonry partition walls, wooden beam ceilings, wooden stairs, roof rafter, tail caver, gutters and drain pipes, internal plasters, external plasters, windows, doors, glazing, wooden floor, wall coatings, woodwork oil coatings, cores of ceramic cookers, tiled stove, central heating pipes, boilers and heaters for c.h., water supply and sewage pipes, water supply and sanitation fittings, gas pipes, electrical installations, electrical equipment). A determined material-structure solution with characteristic theoretical average durability periods $T_{R i}, T_{R i}$ by periods $[1,16,18]$ was assumed for each component.The relations (2.10) and (2.11) were applied to examine the change in the exploitation reliability of all 
the components within the assumed a 100-year period of exploitation. The selected results of calculations are presented in figures $1-6$.

MASONRY WALLS

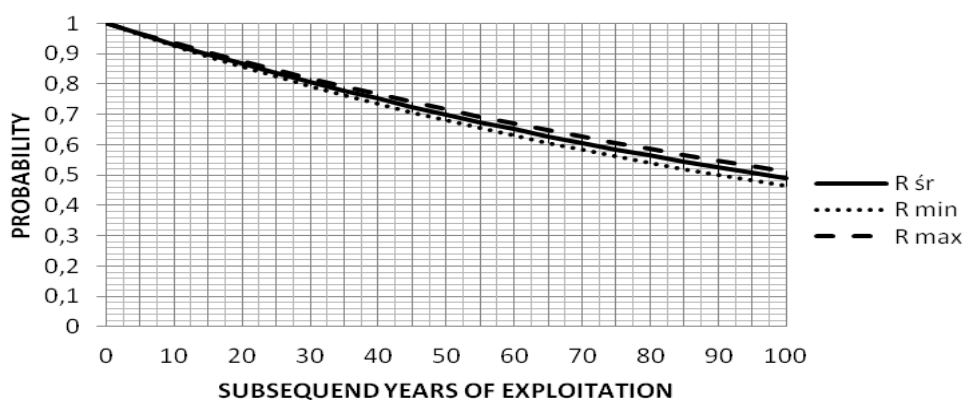

Fig. 1. Reliability prediction of masonry walls according to the exponential distribution

\section{MASONRY WALLS}

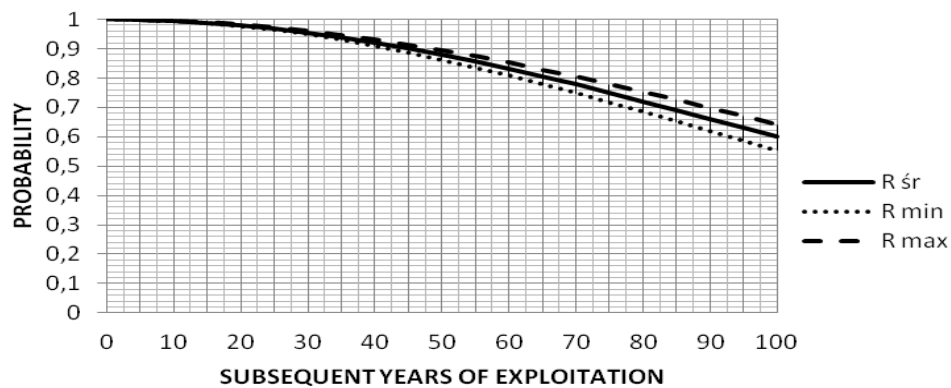

Fig. 2. Reliability prediction of masonry walls according to the Rayleigh distribution

WOODEN RAFTER

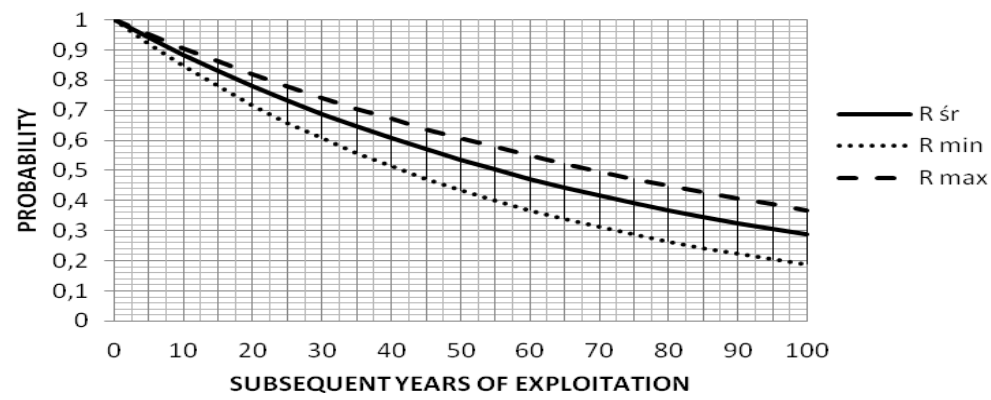

Fig. 3. Reliability prediction of wooden rafter according to the exponential distribution 


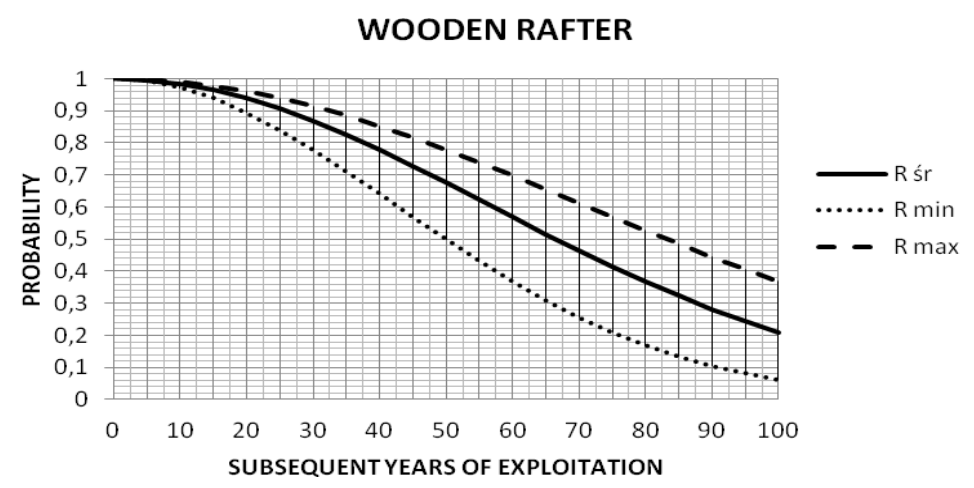

Fig. 4. Reliability prediction of wooden rafter according to the Rayleigh distribution

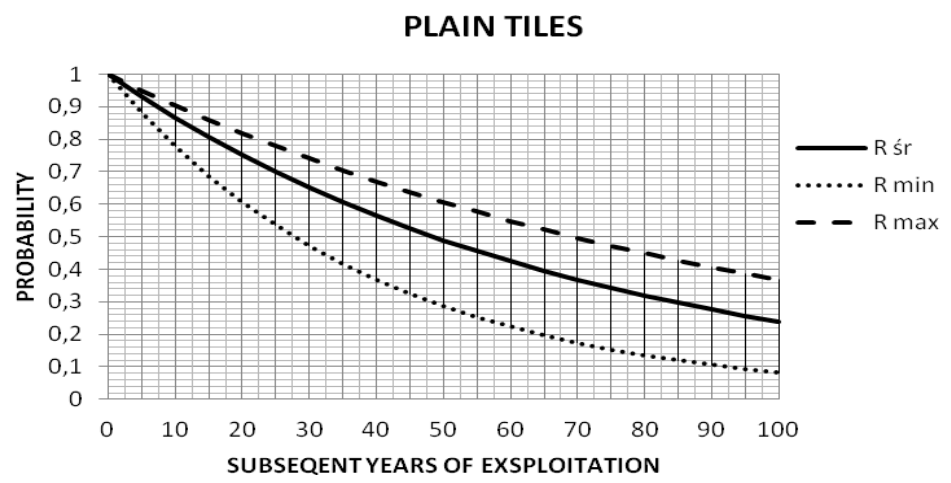

Fig. 5. Reliability prediction of plain tiles according to the exponential distribution

PLAIN TILES

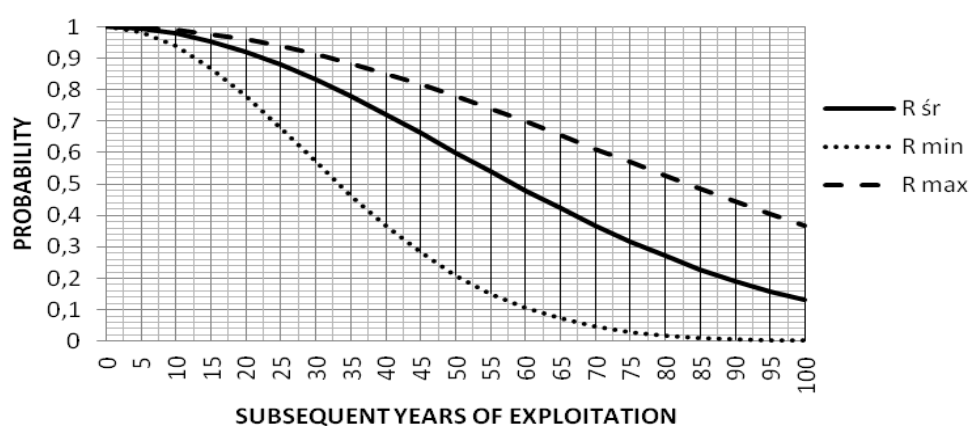

Fig. 6. Reliability prediction of plain tiles according to the Rayleigh distribution 
Due to various reasons of damages to building components occurring with random intensity and frequency (e.g. the influence of atmospheric processes is different on each floor of a building; traffic intensity may cause different damages to buildings of identical structure-material solutions; similarly, different ways of building maintenance, topographic conditions; neighboring trees and many other factors), the periods of component durability may vary considerably from the ones assumed, and thus, the change in the exploitation reliability within an exploitation period will be different. Therefore, the changes in the exploitation reliability in the subsequent years of exploitation presented in the figures should be treated as approximate.

\section{SUMMARY}

Methods derived from the theory of exploitation of machines and electrical appliances were applied to examine the properties of apartment buildings. The results obtained at the present stage of the realisation of the exploitation reliability problem may be helpful in maintenance planning. In order to program repair and renovation work, the prognostic determination of the scope of work in terms of the kind and quantity is necessary. The repairs should include preventive actions aiming at assuring that no damages will occur to the building. The reliability analysis may be applied for predicting the dates of the repairs of the components of a building erected in the traditional technology. The course of the exploitation reliability of elements over the subsequent years of their exploitation may be used in prognostic planning of inter-repair cycles for the whole building.

\section{REFERENCES}

1. Achterberg G., Hampe K.H.: Baustoffe und Bauunternehmungskosten Wirtschaftlich günstige Relationen von Herstellung und Unterhaltungskosten der Gebäude. Schriftenreihe Bau und Wohnforschung des Bundesminister für Raumordnung, Bauwesen und Städtebau, Heft 04.051, Nds MBL nr 43 1976.

2. Bucior J.: Fundamentals of reliability. Publisher Rzeszow University of Technology 1989.

3. Corner P.: 11th Advances in Reliability Technology Symposium. Elsevier Applied Science, Barking 1990.

4. Knyziak P.: Analysis of the technical state for large-panel residential buildings using artificial neural networks, 17th International Conference On 
The Application Of Computer Science And Mathematics In Architecture And Civil Engineering, Weimar, Germany, 12 14.06.2006, p. 36.

5. Masters L. W., Brandt E.: Systematic Methodology for Service Life Prediction of Building Materials and Components. Materials and Structures nr 22/1989.

6. Murzewski J.: Reliability engineering structures Arkady, Warszawa 1989.

7. Nireki T.: Service life design. Construction and Building Materials, Vol. 10, No 5, 1996 Elsevier Science Ltd, Printed in Great Britain 1996.

8. Nizinski S., Pelc H.: Diagnosis of mechanical equipment. Publisher of Science and Technology, Warszawa 1990.

9. Nowak A. S., Collins K. R.: Reliability of Structures, Mc Graw-Hill Int. Edition 2000.

10. Nowogońska B.: Reliability of building determined by the durability of its components. Civil Environmental Engineering Reports $2011 \mathrm{nr}$ 6: 173-180.

11. Runkiewicz L.: Zasady kontroli $i$ oceny jakości remontów $i$ wzmocnień konstrukcji budowlanych. Zeszyt Naukowy Politechniki Wrocławskiej Nr 71, Wrocław, 1998.

12. Salamonowicz T.: Models reliability serviceable objects of preventive service. The Journal Issues machine operation, issue 2/2001.

13. Skarzyński A.: Próba ogólnej systematyki sytuacji kryzysowych oraz wybranych towarzyszacych im dziatań techniczno-organizacyjnych. Materiały konferencyjne XI Konf. IWIiZSK, Warszawa, 2000, s. 202 - 224.

14. Sotskow B. S.: Reliability of components and automation equipment. Publisher of Science and Technology,Warszawa 1973.

15. Szczepiński W., Koltulski Z.: Error Analysis with Applications in Engineering, Institute of Fundamental Technological Research, Polish Academy of Science, Warszawa 1995.

16. Ścislewski Z.: Trwatość budowli. Wydawnictwo Politechniki Świętokrzyskiej, Kielce 1995.

17. Walpde R. E., Myers R. H.: Probability and Statistics for Engineers and Scientists, Macmillan Publishing Company, London 1985.

18. Winniczek W.: Valuation of buildings and structures from reconstruction approach CUTOB-PZITB, Wrocław 1993.

19. Zaidi A., Bouamama B., Tagina M.: Bayesian reliability models of Weibull systems: state of the art. International Journal of Applied Mathematics and Computer Science, 2012, vol. 22, no 3, pp. 585-600. 


\section{MATEMATYCZNY MODEL OPARTY NA ROZKŁADZIE RAYLEIGHA ZMIAN NIEZAWODNOŚCI ELEMENTÓW SKŁADOWYCH BUDYNKU}

\section{Streszczenie}

Planowanie działań związanych z prawidłowym utrzymaniem budynku należy do zadań niełatwych. Brakuje wiarygodnych modeli matematycznych, które pozwalałyby na oszacowanie niezawodności eksploatacyjnej budynku, określanej często zmianami właściwości użytkowych. W przypadku urządzeń technicznych (mechanicznych, elektronicznych) podejmowane są próby wyznaczania predykcji niezawodności eksploatacyjnej, jednak dla obiektów budowlanych podaje się jedynie orientacyjne wykresy zmian właściwości użytkowych. W artykule przedstawiona jest metodyka prognozowania niezawodności eksploatacyjnej budynku, a wartości właściwości użytkowych określone zostały parametrami dystrybuanty rozkładu Rayleigha.

Słowa kluczowe: niezawodność eksploatacyjna, stopień zużycia, predykcja

Editor received the manuscript: 12.11.2014 